\title{
リン酸形燃料電池の劣化モードの経時変化
}

\begin{tabular}{|c|c|c|c|c|c|c|c|}
\hline & 수 & 目 & 青 & 木 & & 努 & (東芝 \\
\hline & 今 & E & 小 & 上 & 泰 & 司 & (東芝) \\
\hline & 今 & 員 & & $\square$ & 忠 & 彦 & (東芝) \\
\hline & 会 & 員 & & 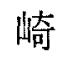 & 芳 & & 東芝) \\
\hline & & 員 & & $川$ & 尚 & & （東 \\
\hline
\end{tabular}

\section{History of PAFC Fuel Cell Performance Degradation Mode.}

Tsutomu Aoki, Non-member, Yasuji Ogami, Non-member, Tadahiko Taniguchi, Non-member, Yoshima Iwasaki, Non-Member, Hisao Nishikawa, Member (Toshiba Ltd.)

\begin{abstract}
It is desirable to establish the accelerate evaluation method for phosphoric acid fuel cell durability in order to promote the PAFC's utilization. It is necessary to clarify the mechanism of voltage loss and investigate the accelerate factors for the establishment of test method. The accelerate factors of voltage loss has been defined by the subscale cell tests and it was found that the temperature is the key factor which accelerate the cell voltage loss by fullscale and subscale test. This paper focused the voltage loss by the gas diffusion which appeared after long time run and investigated the voltage loss mode change and the relation between the loss mode and an accelerate factor by the result of fullscale cell test of 20,000 hour run. It was obtained that the accelerate test by temperature as an accelerate factor could adapt to the prediction of voltage loss till 40,000 hour run.
\end{abstract}

\section{1.まえがき}

リン酸形燃料電池は天然ガスなどの燃料を改質して得ら れる水素と、空気中の酸素と電気化学的に反応させて直 接電気エネルギーを取出す発電装置である。

この然料電池発電システムはクリーンなエネルギーであ り、発電効率が高い铮から、現在オンサイト電源として広 く使用されることが期待されている。

リン酸を電解質とするリン酸形然料電池は多孔質の炭素 板の片面に触媒を塗布して 2 枚の電極の間に、電解質保持 材を挟んだ棈造となって扔り、この単電池を直列に積層し、 出力を取出している。

リン酸形然料電池の耐久性、信頼性を評価するためには、 一般の材料評偭のような加速寿命試験法がないため、長時 間にわたる実運転条件の評洒をせざるを得ない。リン酸形 燃料電池の今後の夷用化を促進するためには、短時間の評 価、すなわち加速寿命試験法の確立が望まれる。この試験 法確立にあたっては、セル劣化要因の解明 (1) 〜 (6) と加速条 件の娭討が必要である。

このような背景から、小型セルを用い、加速要因として 温度、電流密度及び圧力を選定し、これらをパラメータと した小型セル寿命試験を系統的に実施し、温度がセル少化 の重要な加速因子であることを把握した(7)ー(9)。
加速寿命試験法の確立にあたっては、実寸大セルによる 検証が不可欠である。そこで小型セル試験で求めた温度上 昇による加速寿命試験方法が実寸大セ儿人も適用できるこ とを確認するため、ショートスタックによる加速寿命試験 を実施した引り。本論文では、その内容を更に発展させて、加 速寿命試験結果についての小型セルと実寸大七ルの関係、 セル少化モードの経時変化、七ル少化モードと加速倍数に ついて検討し、これまで未検討であった(7)運転後期にあら われるガス搪散阻害領域を含めた加速寿命試験法の適用可 能性について記述した。

\section{2. 試験方法}

\section{$\langle 2 \cdot 1\rangle$ 供試品}

使用したショートスタック（供試品 $\mathrm{A}$ ）の基本仕様を表 1 に示す。セル面積は $5000 \mathrm{~cm}^{2}$ 級で、セル数は 36、冷却板を 9セル毎に㨂入した。セル毎に電圧センサーを取りつけ、セ ル電圧経時特性を測定すると共に、温度センサーを取りつ けて積層方向のセル内最高温度の分布と積層方向の中央セ ルのセル平面温度分布を測定した。なお、小型セル(供試品 B）は、ショートスタッタ（供試品A）のセル反応部から小 片を切り出して製作した。表1に同時に供試品C及び供試品 Dの仕様を示したが、これは比較検討のため過去に実施し た試験結果を 4 章の「考察」で、使用したことによる。 
表 1 供試品の基本仕㥞及び運転実績

Table. 1. Fundamental specification and operating hours of test samples.

\begin{tabular}{|c|c|c|c|c|c|c|}
\hline & \multicolumn{2}{|c|}{$\begin{array}{c}\text { 供試品A } \\
\text { ショートスタック }\end{array}$} & \multirow{2}{*}{$\begin{array}{l}\text { 供試品B } \\
\text { 小型七ル }\end{array}$} & \multicolumn{2}{|c|}{ 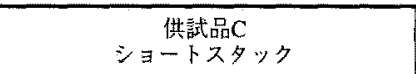 } & \multirow{2}{*}{$\begin{array}{c}\text { 供試品D } \\
\text { フルスック }\end{array}$} \\
\hline & $\overline{A-1}$ & $\mathrm{~A}-2$ & & $\mathrm{C}-1$ & $\mathrm{C}-2$ & \\
\hline $\begin{array}{c}\text { 電流密度 }\left(\mathrm{mA} / \mathrm{cm}^{2}\right) \\
\text { セル数 } \\
\text { セル数/冷却板 } \\
\text { 冷却板数 } \\
\text { サブスック数 } \\
\text { セルサイス } \\
\text { 椧却水入㑁口温度 }\left({ }^{\circ} \mathrm{C}\right) \\
\text { セル最高温度の平均值 }\left({ }^{\circ} \mathrm{C}\right) \\
\text { 運転時間 }(\mathrm{h})\end{array}$ & $\begin{array}{c}200 \\
36 \\
9 \\
5 \\
4 \\
5000 \mathrm{~cm}^{2} \text { 級 } \\
175 / 193 \\
218 \\
5000\end{array}$ & $\begin{array}{c}200 \\
36 \\
9 \\
5 \\
4 \\
5000 \mathrm{~cm}^{2} \text { 級 } \\
157 / 175 \\
200 \\
20000\end{array}$ & $\begin{array}{c}300 \\
\frac{1}{-} \\
- \\
- \\
25 \mathrm{~cm}^{2} \text { 級 } \\
- \\
180 \sim 240 \\
1500 \sim 8000\end{array}$ & $\begin{array}{c}250 \\
24 \\
6 \\
5 \\
4 \\
10000 \mathrm{~cm}^{2} \text { 䄲 } \\
175 / 193 \\
217 / 208 \\
18000\end{array}$ & $\begin{array}{c}250 \\
24 \\
6 \\
5 \\
4 \\
10000 \mathrm{~cm}^{2} \text { 級 } \\
175 / 193 \\
217 / 208 \\
5000\end{array}$ & 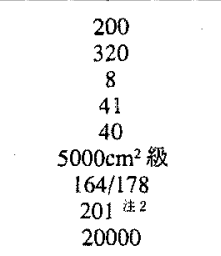 \\
\hline 考 & $\begin{array}{c}\text { 加速寿命試娩 } \\
\text { 七ル毎の電圧測定 }\end{array}$ & $\begin{array}{c}\text { 基準温度試験 } \\
\text { サブスタック毎の } \\
\text { 電圧測定 }\end{array}$ & $\begin{array}{l}\text { 供試品Aの反応部 } \\
\text { から切り出し製作 }\end{array}$ & \begin{tabular}{|c|} 
強揆水性 \\
サブス多ック毎の \\
電圧貺定
\end{tabular} & \begin{tabular}{c|} 
弱揆水性 \\
サブスタック每の \\
麗圧測定
\end{tabular} & $\begin{array}{c}\text { フィールド試験結果 } \\
\text { 七ル電厓は全セルの } \\
\text { 平均㥀を示す }\end{array}$ \\
\hline
\end{tabular}

注 1 : 中央サブスタックと端部サブスタックの值 (七ル平均温度の平均値は $207 / 200^{\circ} \mathrm{C}$ ), 注 2 : 端部サブスタックを除いたサブスタックの平均温度は1920

\section{$\langle 2 \cdot 2\rangle$ 試験条件}

温度がセル少化の加速因子であることから、ショートス タックの試験条件は基準温度（A-2）に対し、1 $8^{\circ} \mathrm{C}$ 上昇させ

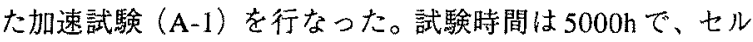
劣化の要因を把握するため、500h 每に I-V 特性、酸素利用 率、水素利用率試験を実施した。試験条件を表 $2 に$ 示す。な お、小型セル試験は電流密度が $300 \mathrm{~mA} / \mathrm{cm}^{2}$ で、温度を 180 ${ }^{\circ} \mathrm{C} \sim 240^{\circ} \mathrm{C}$ 範囲で変化させた。

\section{3. 試験結果}

加速試験と基準温度試験の経時変化を図 1(a)に示す。基 集温度に対し $18^{\circ} \mathrm{C}$ 上昇させることで、セル電圧低下速度 (セル電压低下速度の求め方は文献 (7)、(8)による)は 1.9 倍に増大した。加速試験時のセル毎の経時变化例を図 1(b) に示す。七ル温度が高い程、七ル電圧の低下が大きい。運 転初期（500h 時点）のセル電圧V500 上試験終了時（5000h 時点)のセル電圧V5000との差からセル電圧低下值を求め、 結果を図 2 に示す。積層方向の中央セルはセル温度が高い ため、セル電压の低下值は大きい。一方冷却板に近いセル は、セル温度が低いため、セル電圧の低下值も小さい。セ ル劣化の要因を把握するため、酸素利用率特性及び水素利 用率特性の経時変化を求国 3 に示す。酸素利用率特性は 酸素利用率 $50 \%$ と $80 \%$ に扣ける七ル電圧差、水素利用率特 性は水素利用率70\%と $90 \%$ におけるセル電圧差で示した。

\section{表 2 試験条件}

Table. 2. Test conditions

\begin{tabular}{|c|c|}
\hline 項 目 & 数 \\
\hline 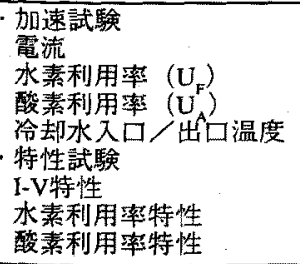 & $\begin{array}{c}1050 \mathrm{~A} \\
80 \% \\
60 \% \\
175 / 193^{\circ} \mathrm{C} \\
280 \mathrm{~A}, 560 \mathrm{~A}, 840 \mathrm{~A}, 1050 \mathrm{~A}, \\
50,70,80,90 \% \text {, at } \mathrm{U}_{\mathrm{A}}=60 \% \\
50,60,70,80 \% \text {, at } \mathrm{U}_{\mathrm{F}}=70 \%\end{array}$ \\
\hline
\end{tabular}

セル電压にバラッキはあるもののどのセルも利用率特性の 経時変化はほとんど見られなかった。これは然料極及び空 気極共にガス拡散阻害によるセル電圧低下はきわめて小さ いことを示している。積層方向の温度分布を図4(a)に示す。 また中央セルのセル平面温度分布を図 $4($ b) に示す。セルの

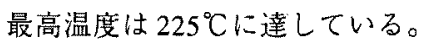

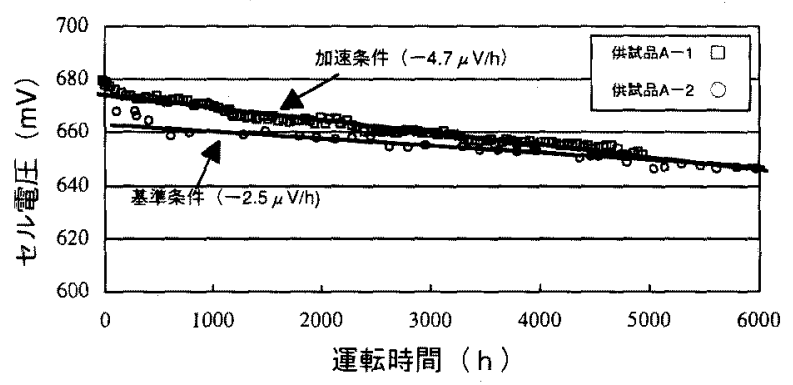

（a）七ル平均電圧経時変化（加速条件と基準条件との比較）

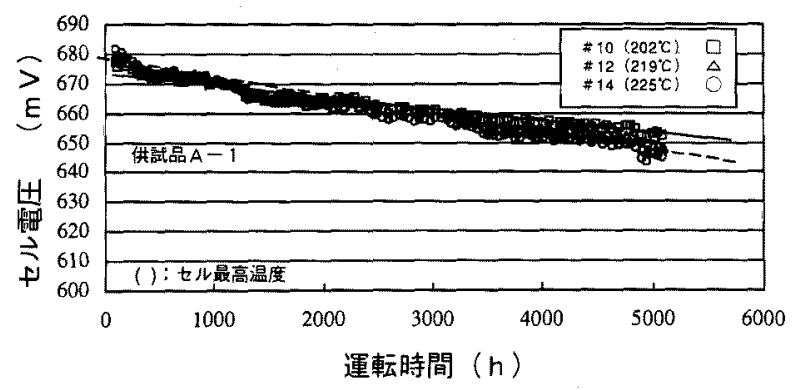

(b) セル電圧経時変化（加速条件におけるセル毎の電圧変化） 図 1 セル電压経時変化

Fig. 1. History of the cell voltage. 


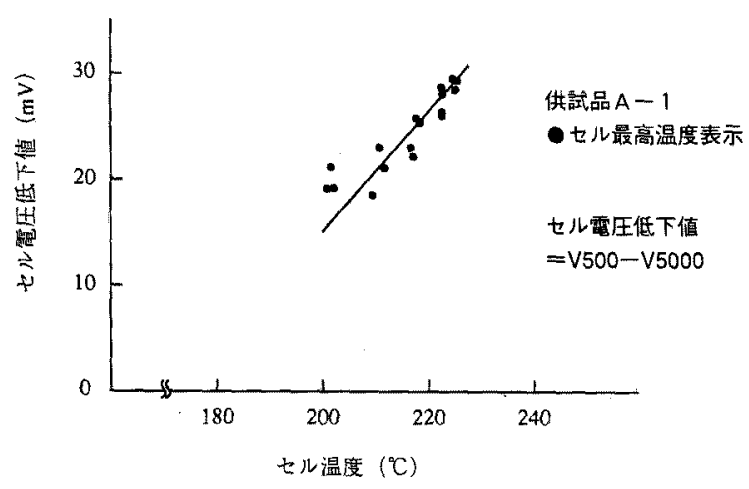

図 2 セル電圧低下值のセル温度依存性

Fig. 2. Temperature effect on cell voltage decay value.

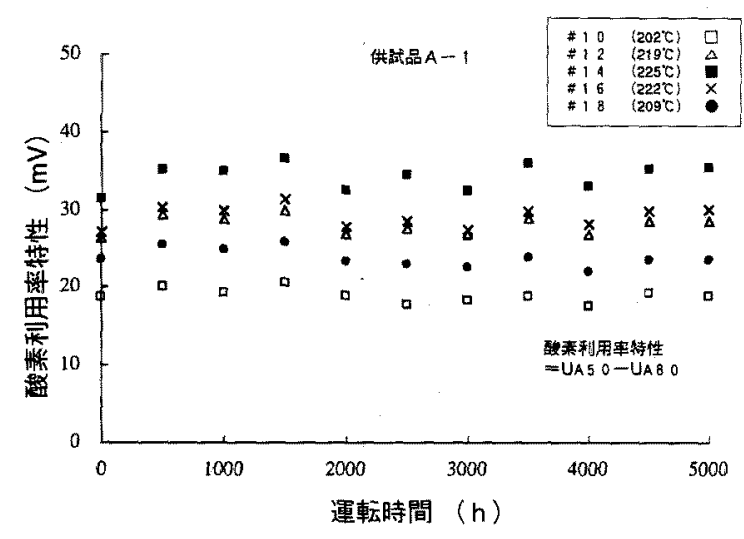

(a) 酸素利用率特性の経時変化

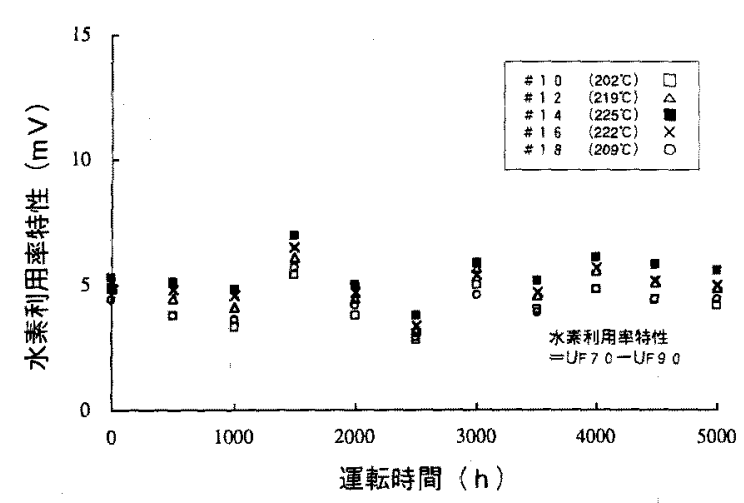

(b) 水素利用率特性の経時変化

図 3 酸素及び水素利用率特性の経時変化

(加速条件におけるセル毎の電圧変化)

Fig. 3. History of $\mathrm{O}_{2}$ and $\mathrm{H}_{2}$ utilization factor gain.

\section{4. 考察}

$\langle 4 \cdot 1\rangle$ セル電圧低下速度とセル温度（小型セルとの比較） 小型七ルとショートスタックのセル電圧低下速度と温度 の関係を図5に示す。小型セルとショートスタックの試験時 の電流密度が異なるが、文献(7、(8)に示すように、電流密度

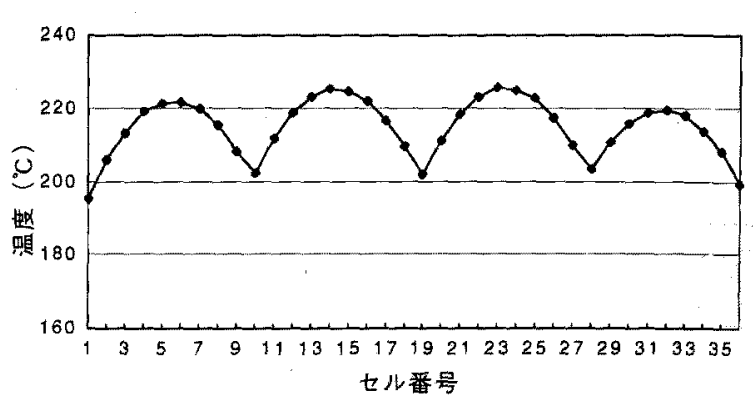

(a) 積層方向のセル温度分布

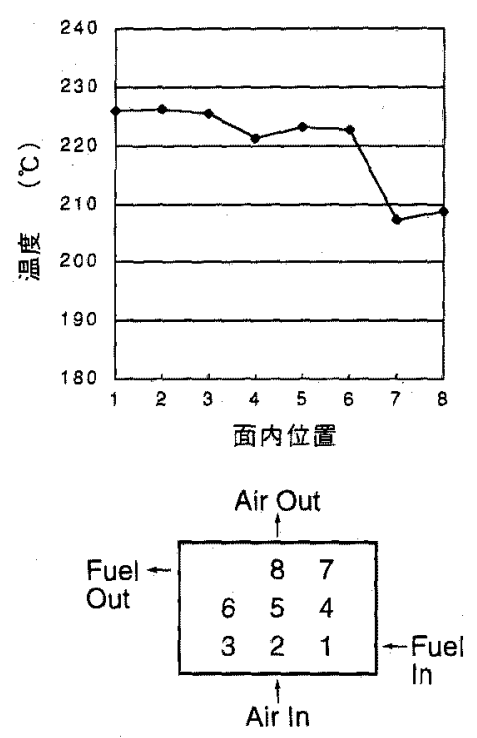

(b) 七ル平面の温度分布

図 4 七儿温度分布（供試品 $\mathrm{A}-1$ ，加速条件）

Fig. 4.Cell temperature distribution.

の七ル電厌低下速度への影響ははとんど見られないことか ら、電流密度の影響を無視して直接比較を行なった。ショー トスタックのセル温度表示として、最高温度表示と平均鼬 度表示の2ケースについて検討した。これらの温度表示とし て、温度測定の実測值を用いて、七ル平面内の温度分布を シミュレーション解析し、25に均等分割した各部分の温度 を求め、最高温度表示とは分割部の最高温度を、七ル平均 温度表示とは、その相加平均值を採用したものである。 セル電圧低下速度とセル温度の関係について、最高温度で 表示すると、ショートスタックのセル電圧低下速度は小型 セルより小さい値を示した。一方、平均温度で表示すると、 小型セルの結果と一致した。これから実寸大セルのセル電 王低下速度は最高温度で決まるのではなく、平均温度で決 まると言える。この理由は、小型セルはセル平面内温度分 布が均一であるのに対し、実寸大七ルは平面内の温度分布 は不均一であるが、(1) 実寸大セルのセル平面内で、細分化 した温度の異なる各部の電圧低下速度はセル平均温度を中 心にほぼ直線的に変化している。(2)高い温度で反応してい 


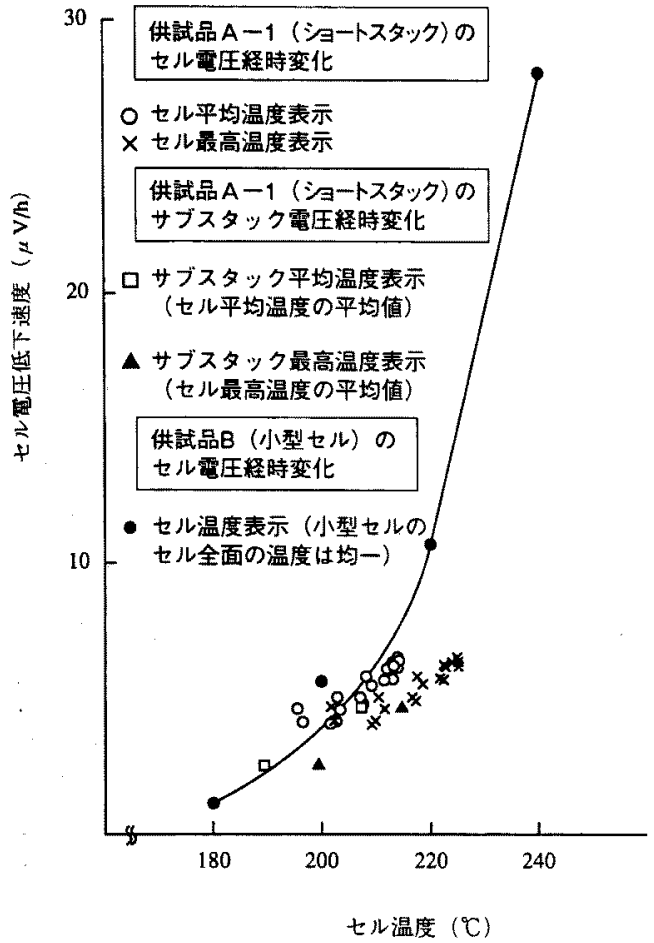

図 5 七ル電圧低下速度の温度依存性

Fig. 5. Temperature effect on cell voltage decay rate.

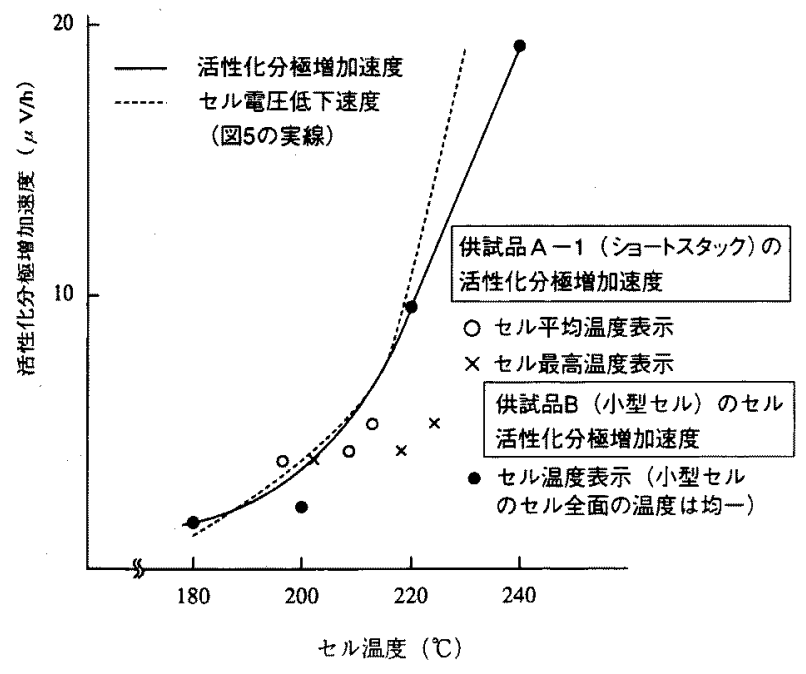

図 6 活性化分極增加速度

Fig. 6. Temperature effect on activation polarization increase rate.

る触媒は劣化が早く、反応は劣化の小さい近くの触媒に移 行し、セル平面内の触媒劣化が均一化の方向に進んでいる ためと考えられる。またサブスタックの平均セル電圧低下 速度もセル毎の経時变化と同樣に、サブスタックのセル平 均温度で決まることが示された。

次にセル劣化要因を把握するため、小型セル試験で求め
た活性化分極增加速度とセル温度の関係を図6に示す。小型 セル試験では定期的に、水素ゲイン、酸素ゲイン試験及び 内部抵抗測定を実施し、その結果をもとに内部抵抗損を除 いた純水素及び純酸素試験条件のセル電圧を推定し、その 経時変化から活性化分極増加速度を求めた。セル温度の 240 ${ }^{\circ} \mathrm{C}$ 除いて、活性化分極增加速度がセル電压低下速度とほ ぼ一致している。ショートスタック試験では、定期的に電

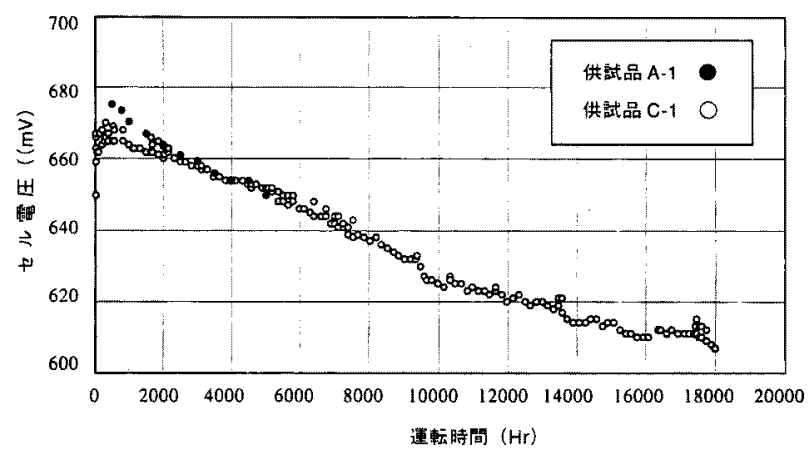

図 7 七ル電圧経時変化比較

Fig. 7. Comparison of cell voltage history.

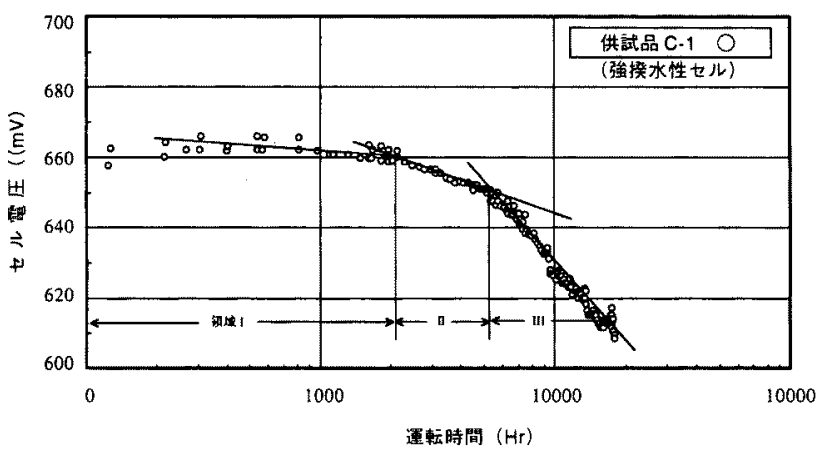

(a) セル電圧経時変化

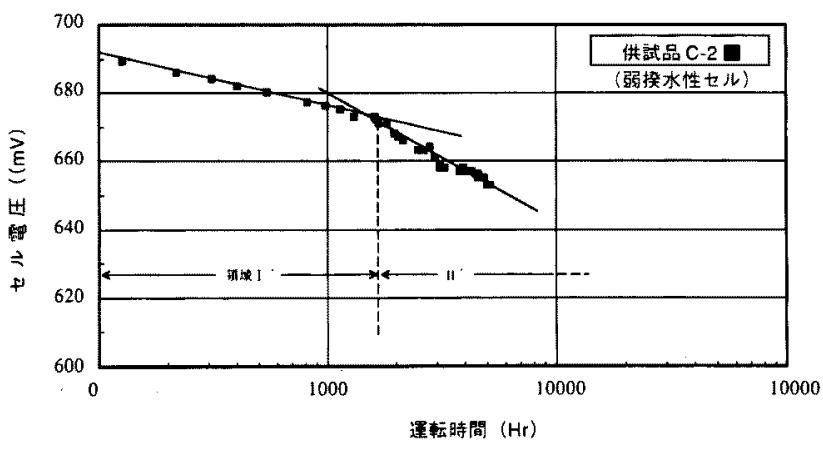

(b) セル電圧経時変化

図 8 七ル電圧経時变化 (対数表示)

Fig. 8. History of cell voltage.

压・電流特性試験を実施している。その結果から文献 (7)に 示す分極分離手法により経時的な活性化分極の变化を推定 した。このようにして求めたショートスタックの活性化分 
極増加速度は図6に示すように、小型セルの活性化分極增加 速度とセル最高温度表示ではなく、七ル平均温度表示の時 に一致している。これから、図5の結果と同様に活性化分極 増加速度はセル平均温度で決まっている。

$\langle 4 \cdot 2\rangle$ 七ル少化モードの経時変化

反応部及び冷却水温度条件がほば等しい供試品 A-1 と供 試品C-1のセル電圧経時変化を図7に示す。似た経時変化を 示した。供試品 C-1 は、18000h までの運転実績を有するの で、この結果をもとに長時間運転時のセル少化モードの経 時変化について検討した。図7を对数表示したグラフを図8 に示す。

経時特性を対数表示することで、経時的なセ儿電圧経過 の特長が明確になる。図 8（a）は揆水性の強いセルの、図 8（b）は揆水性の弱いセルのセル電圧経時特性を示す。セ ルの揆水性が弱い場合は、図8（b）のように、初期の電圧 は高く、また初期の電圧低下も大きい。一方、揆水性の強い 七ルは初期の電圧は小さいが、七ル電圧低下も小さい。図8 (a)に示されるように、セル電圧経時特性を領域 I から III の3つの領域に区分すると、領域Iは運転の初期にあらわ れる現象でセル揆水性の強弱でセル電圧の挙動が大きく変 化すると共に初期の運転条件 (起動、停止操作等)に上って セル電压の挙動が変化している領域と考える。図 8（a）の 七ル電圧経時特性について、前述した手法にもとづき分極 分離した結果を図 9 に示す。I-V 特性試験を初期，2000h, $5000 \mathrm{~h}, 8000 \mathrm{~h}, 14000 \mathrm{~h}, 18000 \mathrm{~h}$ の時点で実施しているため、 ここではセル電圧が安定した $2000 \mathrm{~h} の \mathrm{I}-\mathrm{V}$ 特性を基準とし

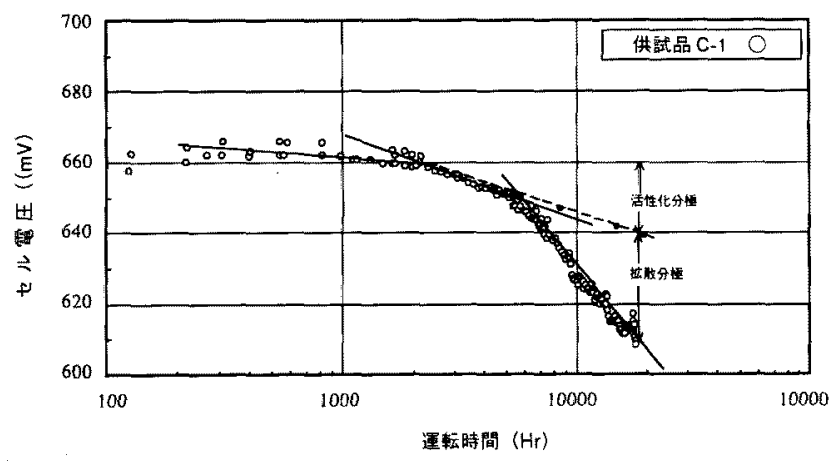

図 9 七儿電圧経時変化 (分極分離結果)

Fig. 9. History of cell voltage activation and diffuson polarization.

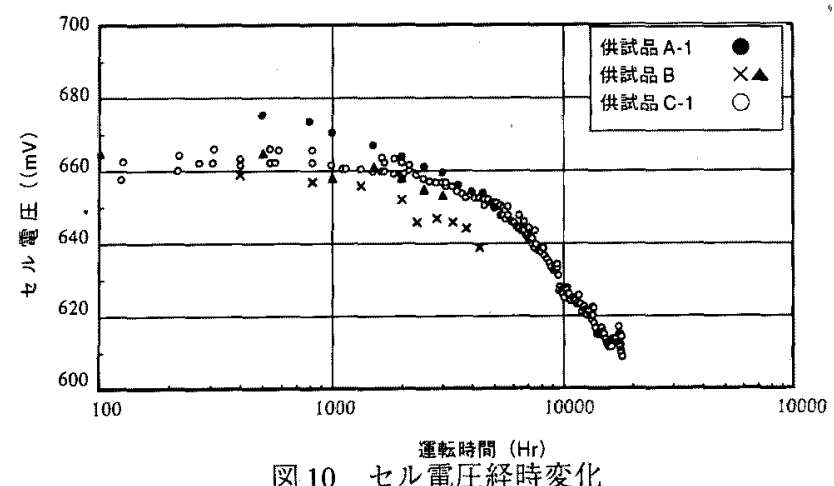

図 10 七儿電圧経時変化

Fig. 10. History of cell voltage.
て、それ以降の活性化分極の增大を求めた。運転開始から 数千時間までは触媒活性低下に起因する活性化分極の增大 が支配的であるが、その後は触媒の劣化に加えて電極の濡 れに起因するガス拡散阻害增大による拡散分極が增大して いる。そして図8（a）のセル電圧経時特性の変曲点で区分 けした領域II と領域IIIがこれら分極增大開始点とほほ一致 している。これまで検討してきたショートスタック(供試 品A-1）と小型セル（供試品B）のセル電圧経時変化を図 10 に示す。く4.1>に示したセル電圧経時特性は数千時間まで の試験結果のため、図9から触媒活性低下領域を主に检討し ていたと言える。

触媒活性低下によるセル電圧低下は対数表示で直線的に 低下するが、ガス桩散阻害によるセル電圧低下も図9に示さ れるように対数表示でほほ直線的に変化していることが試 験結果から示された。

〈4.3〉劣化モードと加速倍数

図 1(a)は、七儿温度が $18^{\circ} \mathrm{C}$ 上昇すると、七儿電圧低下速 度が1.9倍に増大したことを示している。これは図8に示す ように、領域川の現象で、触媒活性低下によるセル電圧低 下が温度の上昇と共に増加したことを示している。セル寿 命 40,000 時間の試験を実施するためには、領域 II に続いて ガス拡散阻害によるセル電圧低下が顕在化する領域III 評佰する必要がある。このため、七ル温度が異なる約 20,000 時間運転した2つの供試品について、どのような挙動を示し たかについて、比較を行なった。供試品C-1と比べ冷却水温 度が $15^{\circ} \mathrm{C}$ 低い供試品 Dの七儿電圧経時特性を図 11 に示し た。定量的な把握のため、領域I と II のセル電圧低下速度 を数値化し結果を表 3 に示した。領域IIIでは、時間軸を直 線表示すると下に凸のカーブとなるため、比較検討が容易 となるようにセル電圧低下速度を対数表示で記述した。温 度の低い供試品 Dのセル電圧低下速度を基準として、温度 の高い供試品 C-1のセル電圧低下速度の加速掊数を領域 II とIIIについて求め結果を表 3 に示す。領域II と III とで、七 儿電圧低下の劣化モードが異なるにもかかわらず、それぞ れの領域の加速倍数はほほ等しい值を示した。

供試品C-1は表1に示すように、中央サブスタックと端部

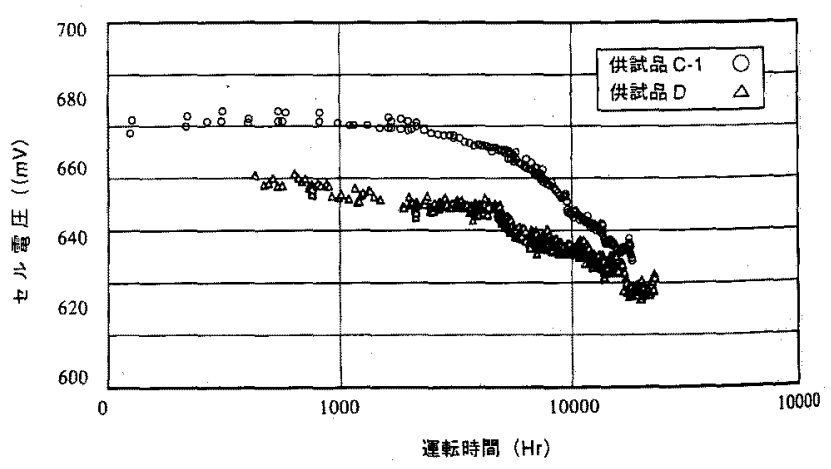

図 11 セル電圧経時変化

Fig.11. History of cell voltage. 
表 3 七ル電压低下速度の比較

Table. 3. Comparison of cell voltage decay rate.

\begin{tabular}{c|c|c}
\hline & 領 域 II & 単位: mV/decade \\
\hline (a) 供試品C-1 & 23 & 78 \\
(b) 供試品D & 12 & 40 \\
\hline $\begin{array}{c}\text { 七ル電壬低下速度の比較 } \\
\text { (a)/ (b) }\end{array}$ & 1.9 & 2.0 \\
\hline
\end{tabular}

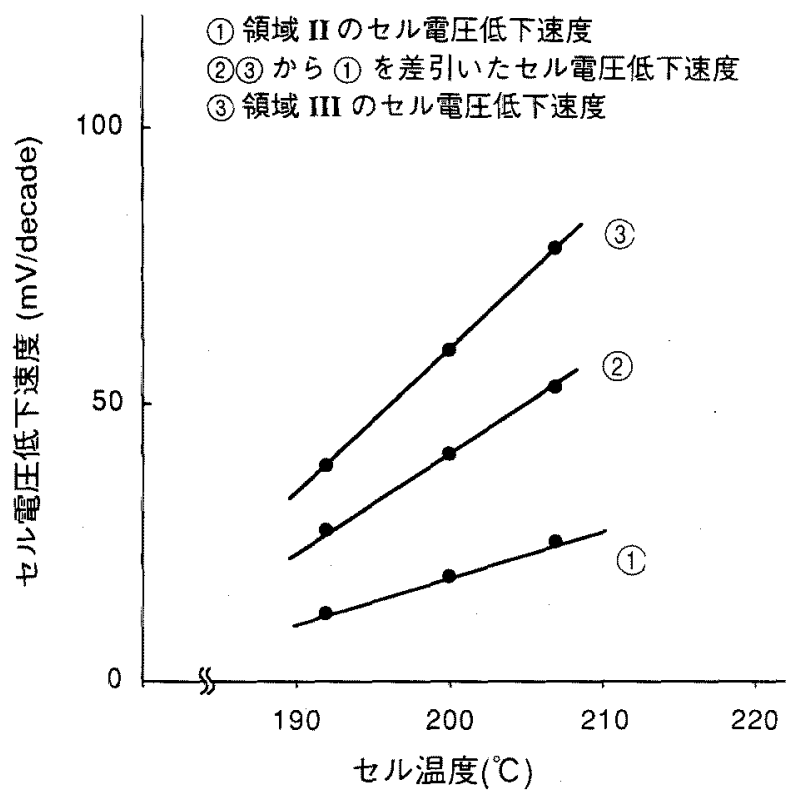

図 12 七ル電圧低下速度の温度依存性

Fig.12. Temperature effect on cell voltage decay rate.

サブスタックでサブスッタタ平均温度を異にしている。そ こで供試品C-1の平均温度の異なる2つのサブスタックの経 時特性と供試品 D の経時特性から領域II と IIIのセ儿電圧低 下速度を求め、結果を図 12 に示す。図 12 の直線(1)は領域 IIの七ル電圧低下速度を、(3)は領域IIIの七ル電圧低下速度 を、(2)は (3)から (1)を差引いたセル電圧低下速度を示す。

ここで図 9 に示されるように領域川のセル電圧低下は触 媒劣化に起因する活性化分極の増大、領域 IIIの七儿電圧低 下祍媒の劣化に数干時間が経過して顕在化するがス搪散 阻害によるセル電圧低下が加算されたものと考えられるの で、(3)から(1)を差引いたセル電圧低下はガス拡散阻害によ るセル電圧低下と想定され、このガス拡散阻害によるセル 電压低下速度(2)も図120ように温度の上昇によって加速さ れることが示された。

以上の検討結果により、セル劣化のモードが異なる領域II と、領域川滥度によるセル劣化の加速性が確認されたこ とから、温度を加速因子とした加速寿命試験法は 40,000 時 間を目標とした時間領域まで適用できるとの見通しが得ら
れた。なお上記の検討は現象面から推定した結果である。今 後は特に領域IIIのガス拡散阻害のメカニズムの解明とその 温度の依存性について、物性面からの解析を行なうことで、 温度を加速要因とした加速寿命試験の信頼性が向上する。 この分野の研究が望ま机る。

\section{5.まとめ}

温度をセル劣化因子とした加速寿命試験法が小型七ルと 同椂にショートスタックにも適用できること確認するた め、ショートスタックの加速寿命試験を実施するとともに、 過去に実施した試験結果を評価し、下記の結果を得た。

（1）小型セルと実寸大セルの此較では、実寸大セルのセル "電压低下速度はセル最高温度でなく、セル平均温度で 決まる。またサブスタックの平均セル電压低下速度は サブスタックの平均温度で決まる。

（2）長時間運転時の経時特性は大きく3つの領域に区分さ れる。領域Iは七ル揆水性の強弱と初期の運転条件に よってセル電圧挙動が大きく変化する箕域である。領 域IIは主に触媒活性低下による活性化分極の増加が、 また領域III は触媒の劣化に加えて電極の需れに起因 するガス搪散阻害による搪散分極の增加が支配する領 域と考えられる。また領域 II 及び領域 III のセ儿電圧 経時特性は対数表示で直線的に変化している。

(3) 領域 IIの七ル電压低下速度と共に領域 IIIの七ル電圧 低下速度も温度によって加速されている。これから温 度をセル劣化の加速要因とした加速寿命試験法はセル 寿命 40,000 時間を目標とした長時間領域まで適用で きる見通しが得られた。

本研究は新エネルギー・産業技術総合開発機構及びリン酸 形燃料電池発電技術研究組合との共同研究結果の一部であ り、関傒者に感謝する。

(平成 10 年 8 月 12 日受付、同 10 年 12 月 24 日再受付)

$$
\text { 文献 }
$$

（1）伊藤幸二，桜并正博，小松正，三輪英幸， “リン酸形燃料電池の特性劣化要因と寿命予測” Denki Kagaku,57,No.6,1989.pp.578-581

（2）荒金淳，漆烟正明，村橋俊明 “リン酸形燃料電池に扔ける白金利用率” Denki Kagaku,63,No.7,1995.PP.642-647

(3) J.Aragane, T.Murahashi and T.Odaka.

"Change oh Pt distribution in the active components of phosphoric acid Fuel Cell."

J.Electrochem,Soc, Vol.135, No.4.1988. pp. $845-850$

(4) J.Aragane,H.Urushibata and T.Murahashi.

"Evaluation of an Effective Platinum Metal surface Area in a phosphoric Acid Fuel Cell"

J.Electrochem Soc, Vol.141,No.7,July 1994. PP.1804-1808 
(5) M.Watanabe,M.Tomikawa and S.Motoo.

"Experimental analysis of the reaction layer structure in a gas diffusion electrode."

J.Electroanal.chem,195.1985.PP.81-93

(6) M.Watanabe,K.Makita,H.Usami and S.Motoo.

"New preparation method of a high performance gas diffusion electrode working at $100 \%$ utilization of catalyst cluster and analysis of the reaction layer." J.Electroanal.chem,197.1986.PP.195-208

(7) 新エネルギー産業技術総合開発機構、“リン酸形燃料 電池寿命評価研究 (加速試験法の開発)”。平成 8 年度 共同研究成果報告書。

(8) 西川尚男、小上泰司、松本正昭、原嶋孝一、渡辺政廣 “リン酸形燃料電池のセル電圧低下の要因について” 電学論 B. 118 巻 7/8 号、平成 10 年. pp. 874-882.

青木 努 (非会員) 1955 年 4 月 11 日生まれ。1981年3月東

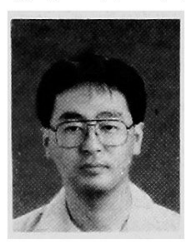
京工業大学理工学研究科化学工学専攻修了。 同年 4 月 (株) 東芝に入社。リン酸型燃料電 池の研究開発に従事。現在電力・産業システ ム技術開発センターにて固体高分子型燃料 電池の開発に従事。

小上 泰司 (非会員) 1959 年 5 月 3 日生まれ。1983 年 3 月 名古屋工業大学金属工学科卒。同年4月（株） 東芝に入社。1984年より重電技術研究所に てリン酸型燃料電池の開発に従事。現在電 力・産業システム技術開発センターにて固 体高分子型燃料電池の開発に従事。
谷口 忠彦 (非会員) 1963年 12 月 29 日生まれ。1988年3月

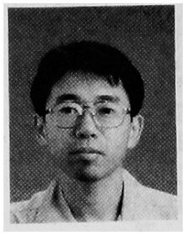
大阪大学大学院理学研究科物理学専攻修了。 同年 4 月（株）東芝入社。主としてリン酸型 燃料電池の開発、研究に従事。現在電力・産 業システム技術開発センターにて固体高分 子型燃料電池の開発に従事。

岩崎 芳摩 (非会員) 1955 年 12 月 1 日生まれ。1974年 3 月

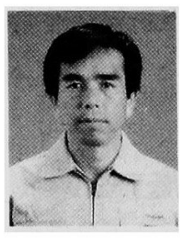
会津工業高等学校卒業。同年 4 月（株）東芝 浜川崎工場に入社。1985 年よりリン酸燃料 電池の開発に従事。

西川 尚男（正員）1940 年 4 月 23 日生まれ。1965 年 3 月

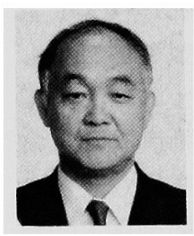
北海道大学電気工学科修士修了。同年 (株) 東芝に入社。主として研究所にて、しゃ断 器、中圧開閉装置、リン酸型燃料電池の開 発研究に従事。工博。IEEE 会員。 